\title{
Spatial patterns of mercury in biota of Adirondack, New York lakes
}

\author{
Xue Yu $\cdot$ Charles T. Driscoll $\cdot$ Mario Montesdeoca $\cdot$ \\ David Evers • Melissa Duron · Kate Williams • \\ Nina Schoch $\cdot$ Neil C. Kamman
}

Accepted: 7 June 2011/Published online: 21 June 2011

(C) The Author(s) 2011. This article is published with open access at Springerlink.com

\begin{abstract}
We studied the spatial distribution patterns of mercury $(\mathrm{Hg})$ in lake water, littoral sediments, zooplankton, crayfish, fish, and common loons in 44 lakes of the Adirondacks of New York State, USA, a region that has been characterized as a "biological Hg hotspot". Our study confirmed this pattern, finding that a substantial fraction of the lakes studied had fish and loon samples exceeding established criteria for human and wildlife health. Factors accounting for the spatial variability of $\mathrm{Hg}$ in lake water and biota were lake chemistry $(\mathrm{pH}$, acid neutralizing capacity (ANC), percent carbon in sediments), biology (taxa presence, trophic status) and landscape characteristics (land cover class, lake elevation). $\mathrm{Hg}$ concentrations in zooplankton, fish and common loons were negatively associated with the lake water acid-base status ( $\mathrm{pH}, \mathrm{ANC}$ ). Bioaccumulation factors (BAF) for methyl $\mathrm{Hg}(\mathrm{MeHg})$ increased from crayfish (mean $\log _{10} \mathrm{BAF}=5.7$ ), to zooplankton (5.9), to prey fish (6.2), to larger fish (6.3), to common loons (7.2). MeHg BAF values in zooplankton, crayfish, and fish (yellow perch equivalent) all increased
\end{abstract}

Electronic supplementary material The online version of this article (doi:10.1007/s10646-011-0717-y) contains supplementary material, which is available to authorized users.

X. Yu $(\bowtie) \cdot$ C. T. Driscoll · M. Montesdeoca

Department of Civil and Environmental Engineering,

Syracuse University, Syracuse, NY 13244, USA

e-mail: xuyu@syr.edu

D. Evers · M. Duron - K. Williams - N. Schoch

BioDiversity Research Institute, Gorham, ME 04038, USA

N. C. Kamman

Vermont Department of Environmental Conservation, Water Quality Division,

Waterbury, VT 05671, USA with increasing lake elevation. Our findings support the hypothesis that bioaccumulation of $\mathrm{MeHg}$ at the base of the food chain is an important controller of $\mathrm{Hg}$ concentrations in taxa at higher trophic levels. The characteristics of Adirondack lake-watersheds (sensitivity to acidic deposition; significant forest and wetland land cover; and low nutrient inputs) contribute to elevated $\mathrm{Hg}$ concentrations in aquatic biota.

Keywords Spatial distribution - Methylmercury · Bioaccumulation - Aquatic biota $\cdot \mathrm{pH} \cdot$ Acid neutralizing capacity

\section{Introduction}

Mercury $(\mathrm{Hg})$ is a toxic metal that can threaten both human and ecological health, due to its strong tendency to bioaccumulate along food webs (Driscoll et al. 2007c; Bookman et al. 2008). Evers et al. (2007) conducted a spatial analysis using indicators of $\mathrm{Hg}$ contamination for human health (i.e., Perca flavescens; yellow perch) and wildlife health (i.e., Gavia immer; common loon) across northeastern North America. Five "biological $\mathrm{Hg}$ hotspots" were identified based on this analysis. The Adirondack region of New York State, U.S. is considered a biological Hg hotspot (Evers et al. 2007, 2008), largely due to the sensitivity of lake-watersheds in the region to inputs of atmospheric $\mathrm{Hg}$ deposition.

Separate indicators have been established to protect humans and wildlife from exposure to Hg. The U.S. Environmental Protection Agency (EPA) has indicated a $\mathrm{Hg}$ concentration of $0.3 \mu \mathrm{g} \mathrm{g}^{-1}$ (wet weight, ww) in fish tissue as a water quality criterion under $\S 304$ of the Clean Water Act to guide human consumption of fish. Due to the 
detailed quantitative understanding of the physiological and reproductive effects of $\mathrm{Hg}$, the common loon has been widely used, especially in the northeastern U.S., as an indicator of the impacts of $\mathrm{Hg}$ contamination on wildlife (Evers et al. 2003, 2007, 2008). Three dietary concentration thresholds of $\mathrm{Hg}$ in fish tissues have been established to indicate health impacts of common loons: concentrations above $0.16 \mu \mathrm{g} \mathrm{g}^{-1} \mathrm{Hg}$ significantly decrease loon reproduction (Evers et al. 2008); $0.21 \mu \mathrm{g} \mathrm{g}^{-1}$ is the $\mathrm{Hg}$ concentration associated with a $50 \%$ decrease from maximum production of fledged young (Burgess and Meyer 2008); and concentrations above $0.41 \mu \mathrm{g} \mathrm{g}^{-1}$ result in complete reproductive failure (Burgess and Meyer 2008). In addition, Evers et al. $(2007,2008)$ indicated that significant adverse physiological, behavioral and reproductive effects occur above blood $\mathrm{Hg}$ concentrations of $3.0 \mu \mathrm{g} \mathrm{g}^{-1}$ in common loons.

There is considerable lake-to-lake variation in $\mathrm{Hg}$ concentrations in the Northeast (Chen and Folt 2005). Many studies have been conducted on the factors influencing $\mathrm{Hg}$ bioaccumulation in aquatic food webs (Chen and Folt 2005; Kamman et al. 2005; Driscoll et al. 2007c; Bushey et al. 2008; Mason et al. 1996). Lake water chemistry, particularly $\mathrm{pH}$ and dissolved organic carbon (DOC), appears to influence the bioavailability of $\mathrm{Hg}$ at the base of the aquatic food chain (Adams et al. 2009; Dittman et al. 2009). Chen et al. (2005) proposed that indicators such as $\mathrm{pH}$, acid neutralizing capacity (ANC), lake area, and zooplankton abundance are useful in identifying lakes that likely contain fish with high $\mathrm{Hg}$ concentrations. Other studies have shown the importance of wetlands in the transport of $\mathrm{Hg}$ and the production and supply of methyl Hg (MeHg; Hurley et al. 1995; Driscoll et al. 1998, 2007a; Selvendiran et al. 2008). Simonin et al. (2008) suggested that outlet dams and the amount of contiguous wetlands affect $\mathrm{Hg}$ concentrations in fish. Dittman and Driscoll (2009) indicated that $\mathrm{pH}$ and fish condition affect fish $\mathrm{Hg}$ concentrations. Indeed, previous studies have focused on three categories of factors affecting $\mathrm{Hg}$ bioaccumulation in aquatic biota: lake physico-chemistry (e.g., pH, DOC), biology (e.g., taxa presence, trophic status), and landscape characteristics (e.g., land cover class, amount of connected wetlands, elevation) (George and Batzer 2008). Few studies have been conducted to evaluate spatial factors that influence the bioaccumulation of $\mathrm{Hg}$ across the entire aquatic food chain (Kramar et al. 2005; Kamman et al. 2005).

This study was conducted by the Wildlife Conservation Society, BioDiversity Research Institute, and the New York State Department of Environmental Conservation partners in the former Adirondack Cooperative Loon Program to assess the impact of $\mathrm{Hg}$ contamination on common loon populations in the Adirondack Park of New York. We analyzed $\mathrm{Hg}$ concentrations in lake water, littoral sediments, zooplankton, crayfish, fish, and common loon in 44 lakes of Adirondack Park. We established the following hypotheses for this study: (a) lake-watershed attributes (such as water chemistry, land coverage, elevation) regulate the spatial patterns of $\mathrm{Hg}$ and $\mathrm{MeHg}$ concentrations in aquatic biota across trophic levels; (b) the sensitivity of lakes to atmospheric $\mathrm{Hg}$ deposition is established by physio-chemical characteristics of lake-watersheds and the supply of MeHg to the base of the food chain; and (c) the acid-base status of Adirondack lakes ( $\mathrm{pH}, \mathrm{ANC})$ is an important controller of bioaccumulation of $\mathrm{MeHg}$.

\section{Study site, field and analytical methods}

Study site

The Adirondack Park of New York State, USA $\left(43^{\circ} 59^{\prime} \mathrm{N}\right.$, $74^{\circ} 14^{\prime} \mathrm{W}$; 2.4 million ha), contains a unique mountainous landscape of wetlands, northern hardwood and boreal forests, alpine tundra, and approximately 2,800 lakes (Driscoll et al. 1991). The variability of lake characteristics, presence of breeding common loons, and the accessibility of the lakes were the main criteria in selecting the study sites. Forty-four lakes were selected for study (Fig. 1), including several listed in the New York State fish consumption advisory (http://www.nyhealth.gov/publications/2779, accessed March 28, 2011).

Atmospheric deposition is the dominant source of $\mathrm{Hg}$ to the Adirondacks (Driscoll et al. 2007c). Miller et al. (2005) created a spatial distribution model of $\mathrm{Hg}$ deposition across northeastern North America. From their model, atmospheric $\mathrm{Hg}$ deposition is generally estimated to be higher in the southeastern Adirondacks where elevations are higher, and deposition decreases toward the northwest. Using the Miller et al. (2005) model, the mean total deposited $\mathrm{Hg}$ to the study lake-watersheds was estimated to be approximately $20 \mu \mathrm{g} \mathrm{m}^{-2}$ year $^{-1}$, with wet deposition of about $8 \mu \mathrm{g} \mathrm{m}^{-2}$ year ${ }^{-1}$ and dry deposition about $12 \mu \mathrm{g} \mathrm{m}^{-2}$ year $^{-1}$.

Field and laboratory methods

All samples were collected at approximately the same time of year, around August 2003 or 2004. Lake water and sediment samples were collected following "clean handsdirty hands protocols" (USEPA 2001, 2002). Water samples were collected as grab samples at a depth of half meter near the center of the lakes. Surface sediment samples were collected using a modified $50 \mathrm{~mL}$ syringe inserted to a $3-5 \mathrm{~cm}$ depth in lake littoral sediments where crayfish were present. Zooplankton samples were collected via tow nets $(64 \mu \mathrm{m}$ pore size). Crayfish were collected by hand 
Fig. 1 Location of the 44 study lakes in Adirondack Park of New York State. The corresponding lake names for each ID are shown in Table 1

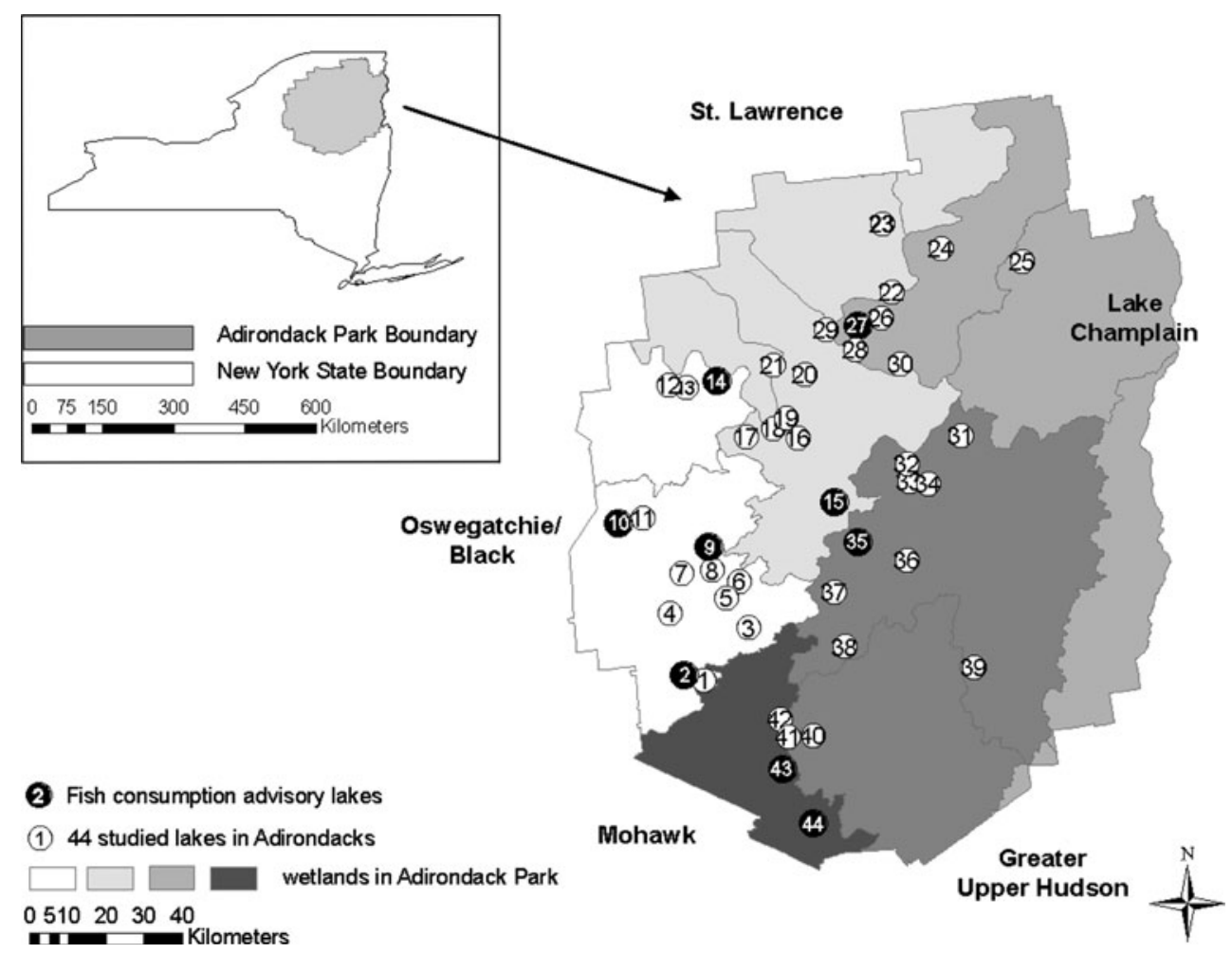

from lakes with rocky substrate. Whole body and tail of crayfish samples were measured for $\mathrm{Hg}$ concentrations. Four size-classes of fish $(5-10 \mathrm{~cm}, 10-15 \mathrm{~cm}, 15-20 \mathrm{~cm}$ and $20-25 \mathrm{~cm}$ ) were collected for whole body analyses using seines, rod and reel, and minnow traps. Loons were captured by night-lighting techniques (Evers et al. 2008), and blood samples were non-lethally collected. We have one sample for water, sediment and zooplankton, two or three samples for crayfish, and multiple samples for fish and loons in each of the 44 lakes. We were unable to collect crayfish from 17 of the lakes and also did not collect sediments from those lakes.

The collected samples were sent to Syracuse University (water, sediments, zooplankton) and Texas A\&M University (crayfish, fish, loon) for chemical analysis. Total $\mathrm{Hg}$ (THg) was analyzed via oxidation, purge and trap, and cold vapor atomic fluorescence spectroscopy (CVAFS, Tekran model 2600) based on USEPA method 1631 (2002, revision $\mathrm{E})$. $\mathrm{MeHg}$ was analyzed via distillation, aqueous ethylation, purge and trap, desorption, and CVAFS based on USEPA method 1630 (2001). All samples were analyzed for THg. MeHg was analyzed in water, sediment, and zooplankton. All biota $\mathrm{Hg}$ and $\mathrm{MeHg}$ concentrations are expressed on a wet weight (ww) basis, except for zooplankton (dry weight, dw). Ancillary water chemistry parameters, including $\mathrm{pH}, \mathrm{ANC}, \mathrm{DOC}$, dissolved inorganic carbon (DIC), $\mathrm{Na}, \mathrm{K}, \mathrm{Ca}, \mathrm{Mg}, \mathrm{Si}, \mathrm{NH}_{4}, \mathrm{NO}_{3}, \mathrm{SO}_{4}, \mathrm{~F}, \mathrm{Cl}$, total phosphorus $(\mathrm{P})$, chlorophyll a, monomeric aluminum
$\left(\mathrm{Al}_{\mathrm{m}}\right)$ and non-labile (organic) monomeric aluminum $\left(\mathrm{Al}_{\mathrm{o}}\right)$, were analyzed from the same sample which was analyzed for $\mathrm{Hg}$ species according to standard methods (APHA/ AWWA/WEF 1998). The determination of $\mathrm{THg}, \mathrm{MeHg}$ and ancillary chemical properties for all water, sediment and biological samples were subjected to quality assurance (QA) procedures which are summarized in the electronic supplementary material.

\section{Data analysis methods}

In this study several different species of fish were collected. We considered golden shiner (Notemigonus crysoleucas), creek chub (Semotilus atromaculatus), and banded killifish (Fundulus diaphanus) to be "prey fish", while yellow perch, pumpkinseed sunfish (Lepomis gibbosus), brown bullhead (Ictalurus nebulosus), smallmouth bass (Micropterus dolomieu), and largemouth bass (Micropterus salmoides) as "fish". To facilitate comparison of fish $\mathrm{Hg}$ concentrations across lakes, we converted all fish $\mathrm{Hg}$ concentrations to yellow perch equivalent values (YPE) based on the New York State Research Development Authority (NYSERDA) fish tissue standardization approach (Kamman et al. 2003). In designing the project dataset, the fish collected were grouped into four size classes (described above). In so doing, we paired yellow perch $\mathrm{Hg}$ concentrations with $\mathrm{Hg}$ concentrations of other fish species within lake and size categories to calculate 
predictive linear relationships that took the form of linear regressions or simple adjustment factors. Ultimately, we computed modeled YPE from other fish species for all lakes in this study.

Similarly, to facilitate the comparisons of blood $\mathrm{Hg}$ concentrations among samples of loons (including females, males and juveniles), we converted values into equivalent female loon concentrations, or female loon unit (FLU) concentrations. We used a compilation of common loon data from New York state (1998-2008, $n=381$ ), whose subsets contained multiple $\mathrm{Hg}$ observations for loons from a single territory and year, to develop the modeled conversion relationships. The equation used to convert male blood $\mathrm{Hg}$ concentrations into FLU was: FLU $=\exp (-0.64939+$ $\left.1.354711 * \ln \left(\mathrm{Hg}_{\text {male }}\right)\right), r^{2}=0.61,95 \%$ confidence limits (CL): 1.073-1.739. While the equations used to convert juvenile blood samples into FLU values were: age $<4$ weeks, $\mathrm{FLU}=\exp \left(1.117769+0.441887 * \ln \left(\mathrm{Hg}_{\text {juv }}\right)\right), r^{2}=0.58$, 95\% CL: 0.324-0.571; age from 4 to 6 weeks, FLU $=\exp$ $\left(1.818148+0.752218 * \ln \left(\mathrm{Hg}_{\mathrm{juv}}\right)\right), r^{2}=0.52,95 \% \mathrm{CL}:$ $0.568-0.976$.

We also used the bioaccumulation factor (BAF) to represent the magnitude of $\mathrm{Hg}$ contamination in biota. BAF was expressed as the $\log _{10}$ ratio of $\mathrm{MeHg}$ concentration in biota to MeHg in lake water (Dittman and Driscoll 2009). It was assumed that $\mathrm{THg}$ and $\mathrm{MeHg}$ concentrations are equivalent in crayfish, prey fish, fish and loon samples (crayfish: Pennuto et al. 2005; fish: Watras and Bloom 1992; Lasorsa and Allen-Gil 1995; loon: Driscoll et al. 2007c).

We used the Statistic Analysis System (SAS 9.1.3, SAS Institute Inc., Cary, NC) software to perform data analysis. To investigate the relationships across trophic levels from lake-to-lake, we pooled data sets according to species and lakes using the SAS Analyst and SAS PROC MERGE tools. We explored the inter-correlations of the lake chemistry parameters with SAS VARCLUS. We analyzed the relationships of $\mathrm{Hg}$ concentrations in biota and various physicochemical, biological and spatial factors using SAS PROC CORR. We conducted multiple regressions to predict biota $\mathrm{Hg}$ concentrations from lake water chemistry and related biology parameters using SAS PROC REG tools with both entry and leaving levels at 0.15. Also, we used analysis of variance (SAS PROC GLM) and Tukey's multiple comparisons to compare $\mathrm{Hg}$ concentrations in biota.

We used Geographic Information System (ESRI ArcGIS 9.3) software to analyze the spatial patterns of $\mathrm{Hg}$ concentrations. We obtained both the digital elevation model (DEM) and National Hydrography Dataset (NHD) of the Adirondack Park from the United States Geological Survey (USGS). We delineated the watersheds for the study lakes via Arc Hydro 1.3 tools based on these datasets. We determined the area percentages of land cover classes for each watershed using the National Land Cover Dataset for 2001 (NLCD, Fry et al. 2009). The atmospheric Hg deposition data were obtained from the spatial maps created by Miller et al. (2005).

A key limitation of this synoptic study is the single collection of $\mathrm{Hg}$ samples for each lake. An inherent assumption in our approach is that samples collected during a single summer collection are representative of annual conditions in water, littoral sediments and across the aquatic food chain. Investigations have noted marked seasonal and spatial variations in water column $\mathrm{Hg}$ concentrations (Selvendiran et al. 2009), and seasonal variations in zooplankton (Slotton et al. 1995). However, multiple collections for each site were beyond the scope of this synoptic survey.

\section{Results and discussion}

General lake water chemistry

The watershed and water chemistry characteristics of each study lake are summarized in Table 1. Most of the Adirondack lakes studied were characterized by relatively low-DOC (35 out of 44 lakes $<5 \mathrm{mg} \mathrm{C} \mathrm{L}^{-1}$ ). The lakes were largely soft water, with a mean $\mathrm{pH}$ of 6.5 (range: 5.3-7.8) and a mean ANC of $105 \mu \mathrm{eq} \mathrm{L}^{-1}$ (range: 4-331 $\mu \mathrm{eq} \mathrm{L}^{-1}$ ). Most of the study lakes were oligotrophic, with low concentrations of total $\mathrm{P}$ (mean: $2.6 \mu \mathrm{g} \mathrm{L}^{-1}$, range: $\left.0-6.0 \mu \mathrm{g} \mathrm{L}^{-1}\right)$ and chlorophyll a $\left(2.8 \mu \mathrm{g} \mathrm{L}^{-1}\right.$, $0.2-15.7 \mu \mathrm{g} / \mathrm{L})$.

$\mathrm{Hg}$ concentrations in the Adirondack Park

\section{Water}

Concentrations of $\mathrm{THg}$ in lake water had a mean of $1.73 \mathrm{ng} \mathrm{L}^{-1}$ and ranged from 0.10 (Clear Pond) to $4.96 \mathrm{ng} \mathrm{L}^{-1}$ (North Lake). Concentrations of MeHg in lake water had a mean of $0.096 \mathrm{ng} \mathrm{L}^{-1}$ and ranged from $<0.002$ (method detection limit, MDL) to $0.48 \mathrm{ng} \mathrm{L}^{-1}$ (Dry Channel Pond). The fraction of THg occurring as MeHg (\% $\mathrm{MeHg} / \mathrm{THg}$ ) had a mean of $6 \%$ and ranged from 0 to $48 \%$ (Dry Channel Pond). A weak relationship was found between $\mathrm{MeHg}$ and $\mathrm{THg}$ in water $\left(r^{2}=0.13, p=0.02\right)$. The individual average $\mathrm{Hg}$ concentrations in water, sediment and biota of each lake are presented in a table in the supplementary material (electronic version only). Estimated total atmospheric $\mathrm{Hg}$ deposition was weakly correlated with $\mathrm{Hg}$ concentrations in lake water $\left(r^{2}=0.10\right.$, $p=0.03)$. Although some study lakes are in close proximity, concentrations of $\mathrm{THg}$ and $\mathrm{MeHg}$ were highly 
Table 1 Lake name, ID, mean major chemistry and lake-watershed characteristics, and location of the 44 study lakes in Adirondacks, the lake IDs correspond to lakes shown in Fig. 1

\begin{tabular}{|c|c|c|c|c|c|c|c|c|c|c|}
\hline Basin & Lake & ID & $\mathrm{pH}$ & $\begin{array}{l}\text { DOC } \\
\mathrm{mg} \mathrm{C} \mathrm{L} \mathrm{L}^{-1}\end{array}$ & $\begin{array}{l}\text { ANC } \\
\mu \text { eq } L^{-1}\end{array}$ & $\begin{array}{l}\text { Chl-a } \\
\mu \mathrm{g} \mathrm{L}^{-1}\end{array}$ & $\begin{array}{l}\text { Elev } \\
\mathrm{m}\end{array}$ & $\begin{array}{l}\text { Area } \\
\text { ha }\end{array}$ & Latitude & Longitude \\
\hline \multirow[t]{14}{*}{ Oswegatchie/Black } & South Lake & 1 & 5.7 & 2.6 & 12.7 & 1.1 & 563 & 191.5 & 43.50583 & -74.8728 \\
\hline & North Lake & 2 & 5.26 & 6.0 & 9.7 & 0.3 & 544 & 263.2 & 43.52033 & -74.9422 \\
\hline & Squaw Lake & 3 & 5.95 & 3.6 & 21.0 & 1.4 & 619 & 22.5 & 43.635 & -74.7367 \\
\hline & Nicks Lake & 4 & 7 & 4.3 & 141.6 & 3.3 & 538 & 55.0 & 43.6695 & -74.9908 \\
\hline & Limekiln Lake & 5 & 6.39 & 2.3 & 38.7 & 0.8 & 511 & 2840.3 & 43.708 & -74.8078 \\
\hline & Seventh Lake & 6 & 7.08 & 4.2 & 188.6 & 0.9 & 563 & 94.0 & 43.742 & -74.759 \\
\hline & Little Safford Lake & 7 & 5.6 & 8.4 & 18.3 & 2.5 & 519 & 18.6 & 43.75667 & -74.9533 \\
\hline & Moss Lake & 8 & 6.6 & 4.4 & 86.0 & 1.9 & 533 & 199.8 & 43.77533 & -74.8518 \\
\hline & Big Moose Lake & 9 & 5.29 & 2.5 & 12.6 & 1.4 & 443 & 0.2 & 43.81733 & -74.8532 \\
\hline & Beaver Lake & 10 & 6.17 & 4.3 & 40.1 & 0.7 & 435 & 261.9 & 43.87617 & -75.157 \\
\hline & Moshier Reservoir & 11 & 6.02 & 4.2 & 21.8 & 0.9 & 531 & 129.6 & 43.88517 & -75.1053 \\
\hline & Newton Falls & 12 & 6.83 & 5.3 & 116.2 & 15.7 & 536 & 556.4 & 44.2085 & -74.9853 \\
\hline & Chaumont Pond & 13 & 6.78 & 4.5 & 119.0 & 2.2 & 469 & 432.2 & 44.205 & -74.942 \\
\hline & Cranberry Lake & 14 & 6.57 & 4.2 & 64.4 & 2.3 & 470 & 154.0 & 44.21917 & -74.8422 \\
\hline \multirow[t]{9}{*}{ St. Lawrence } & South Pond & 15 & 5.99 & 3.7 & 16.1 & 0.8 & 568 & 215.9 & 43.92383 & -74.4528 \\
\hline & Round Lake & 16 & 6.74 & 6.7 & 85.6 & 3.1 & 556 & 135.3 & 44.085 & -74.575 \\
\hline & Lows Lake & 17 & 6.55 & 4.5 & 67.2 & 6.6 & 524 & 1344.9 & 44.086 & -74.7415 \\
\hline & Hitchins Pond & 18 & 6.46 & 4.5 & 79.1 & 2.3 & 500 & 164.7 & 44.10817 & -74.6542 \\
\hline & Horseshoe Lake & 19 & 6.56 & 4.6 & 261.9 & 3.1 & 503 & 152.6 & 44.125 & -74.6243 \\
\hline & Piercefield Flow & 20 & 6.77 & 6.2 & 87.1 & 0.9 & 544 & 48.6 & 44.23333 & -74.5597 \\
\hline & Massawepie Lake & 21 & 7.19 & 3.7 & 235.7 & 2.2 & 526 & 179.0 & 44.25 & -74.6575 \\
\hline & Spitfire Lake & 22 & 7.21 & 2.8 & 176.1 & 2.3 & 576 & 36.4 & 44.4205 & -74.2545 \\
\hline & Clear Pond & 23 & 5.67 & 2.1 & 8.3 & 1.2 & 469 & 159.3 & 44.584 & -74.2837 \\
\hline \multirow[t]{7}{*}{ Lake Champlain } & Kushaqua Lake & 24 & 7.39 & 5.8 & 331.5 & 7.2 & 509 & 66.5 & 44.52317 & -74.1022 \\
\hline & Taylor Pond & 25 & 7.1 & 3.3 & 162.7 & 1.7 & 641 & 29.5 & 44.48933 & -73.8202 \\
\hline & Little Clear Pond & 26 & 7.26 & 1.6 & 250.1 & 2.5 & 512 & 51.0 & 44.35317 & -74.2848 \\
\hline & Long Pond & 27 & 7.82 & 3.7 & 105.7 & 4.7 & 523 & 1063.5 & 44.34167 & -74.4005 \\
\hline & East Pine Pond & 28 & 6.9 & 3.4 & 163.6 & 5.6 & 487 & 692.4 & 44.33717 & -74.4073 \\
\hline & Dry Channel Pond & 29 & 5.74 & 3.7 & 20.4 & 2 & 476 & 27.3 & 44.34233 & -74.442 \\
\hline & Middle Saranac Lake & 30 & 6.96 & 3.9 & 159.0 & 1.6 & 531 & 40.6 & 44.25883 & -74.2397 \\
\hline \multirow[t]{11}{*}{ Upper Hudson } & Henderson Lake & 31 & 6.26 & 2.7 & 30.8 & 1 & 496 & 0.7 & 44.0885 & -74.0555 \\
\hline & Wolf Pond & 32 & 6.93 & 3.0 & 85.9 & 0.3 & 645 & 54.7 & 44.024 & -74.2192 \\
\hline & Arbutus Lake & 33 & 6.72 & 4.1 & 72.5 & 1 & 434 & 44.5 & 43.97633 & -74.2348 \\
\hline & Woodruff Lake & 34 & 7.52 & 6.6 & 283.2 & 12.4 & 653 & 431.7 & 43.95917 & -74.1432 \\
\hline & Lake Durant & 35 & 6.71 & 6.8 & 102.9 & 1.8 & 484 & 104.9 & 43.83733 & -74.3843 \\
\hline & Lake Abanankee & 36 & 6.75 & 3.1 & 106.6 & 2 & 429 & 41.4 & 43.79183 & -74.2245 \\
\hline & Cedar River Flow & 37 & 6.87 & 3.9 & 110.2 & 3.4 & 461 & 358.5 & 43.7225 & -74.47 \\
\hline & Mason Lake & 38 & 6.94 & 3.3 & 172.2 & 2.4 & 525 & 191.0 & 43.58867 & -74.4233 \\
\hline & Garnet Lake & 39 & 7.09 & 3.8 & 203.9 & 4.4 & 494 & 115.2 & 43.53617 & -74.008 \\
\hline & Piseco Lake-Big Bay & 40 & 5.6 & 3.7 & 101.1 & 1.5 & 547 & 199.1 & 43.37533 & -74.5405 \\
\hline & Private Lake \#1 & 41 & 6.18 & 6.0 & 55.6 & 3.7 & 555 & 1.2 & 43.372 & -74.6187 \\
\hline \multirow[t]{3}{*}{ Mohawk } & G Lake & 42 & 6.18 & 2.1 & 23.8 & 1 & 491 & 188.2 & 43.4175 & -74.635 \\
\hline & Ferris Lake & 43 & 5.94 & 4.3 & 32.0 & 1.6 & 488 & 20.0 & 43.30017 & -74.6335 \\
\hline & Canada Lake & 44 & 6.57 & 2.4 & 58.7 & 0.9 & 450 & 3.7 & 43.15817 & -74.5378 \\
\hline
\end{tabular}


variable. $\mathrm{Hg}$ concentrations in lake water were similar to those reported by other studies for the same region (THg: $\quad 0.56-5.07 \mathrm{ng} \mathrm{L}^{-1}, \quad \mathrm{MeHg}$ : $\quad 0.03-0.60 \mathrm{ng} \mathrm{L}^{-1}$, Dittman and Driscoll 2009; THg: 1.36-7.01 ng L ${ }^{-1}$, MeHg: 0.03-0.96 ng L ${ }^{-1}$, Dennis et al. 2005; MeHg: 0.1-0.4 ng $\mathrm{L}^{-1}$, Driscoll et al. 1998).

We conducted SAS VARCLUS procedure to address the inter-correlations of lake water chemistry measurements. We found 3 clusters of variables which explained $48 \%$ of the variability: cluster $1, \mathrm{pH}, \mathrm{DIC}, \mathrm{ANC}, \mathrm{Si}$, chlorophyll a, $\mathrm{Na}, \mathrm{Ca}, \mathrm{Mg}, \mathrm{Cl}, \mathrm{NO}_{3}$; cluster 2, DOC, $\mathrm{THg}, \mathrm{MeHg}, \mathrm{SO}_{4}$, $\mathrm{Al}_{\mathrm{m}}$ and $\mathrm{Al}_{\mathrm{o}}$; and cluster $3, \mathrm{NH}_{4}$, total $\mathrm{P}, \mathrm{K}, \mathrm{F}$. Parameters in cluster 2 were found to be correlated with $\mathrm{THg}$ and $\mathrm{MeHg}$ concentrations in lake water. DOC was slightly positively correlated with $\mathrm{THg}\left(r^{2}=0.18, p=0.002\right)$ but not with $\mathrm{MeHg}$ in lake water. Both $\mathrm{Al}_{\mathrm{m}}$ and $\mathrm{Al}_{\mathrm{o}}$ were positively related to $\mathrm{THg}\left(\mathrm{Al}_{\mathrm{m}}: r^{2}=0.32, p<0.0001\right.$; $\left.\mathrm{Al}_{\mathrm{o}}: r^{2}=0.34, p<0.0001\right)$. Neither $\mathrm{THg}$ nor $\mathrm{MeHg}$ in water were correlated with $\mathrm{pH}$.

\section{Sediments}

THg concentrations in littoral sediments (dw) had a mean of $17.2 \mathrm{ng} \mathrm{g}^{-1}$ and ranged from 1.7 (Moss Lake) to $88.1 \mathrm{ng} \mathrm{g}^{-1}$ (Mason Lake). MeHg concentrations in littoral sediments had a mean of $0.36 \mathrm{ng} \mathrm{g}^{-1}$ and ranged from $<0.002$ (MDL, Lake Abanakee) to $3.63 \mathrm{ng} \mathrm{g}^{-1}$ (Mason Lake). Mean $\% \mathrm{MeHg} / \mathrm{THg}$ in littoral sediments was $2 \%$ and ranged from 0 (Lake Abanakee) to 16\% (Middle Saranac Lake). In contrast to our results for lake water, sediments $\mathrm{MeHg}$ concentrations were strongly correlated with THg concentrations $\left(r^{2}=0.57, p<0.0001, n=29\right)$. We found significant positive correlations between percent organic carbon in littoral sediments with $\mathrm{THg}\left(r^{2}=0.92\right.$, $n=44), \mathrm{MeHg}\left(r^{2}=0.90, n=40\right)$ and $\% \mathrm{MeHg} / \mathrm{THg}$ $\left(r^{2}=0.59, n=40\right.$, all $p$ values $\left.<0.0001\right)$.

\section{Lower food web}

THg concentrations in zooplankton (dw) had a mean of $0.31 \mu \mathrm{g} \mathrm{g}^{-1}$ and ranged from 0.007 (Canada Lake) to $0.89 \mu \mathrm{g} \mathrm{g}^{-1}$ (North Lake). MeHg concentrations in zooplankton had a mean of $0.07 \mu \mathrm{g} \mathrm{g}^{-1}$ (dw) and ranged from 0.0007 (Canada Lake) to $0.25 \mu \mathrm{g} \mathrm{g}^{-1}$ (North Lake). In zooplankton, \% MeHg/THg had a mean of $24 \%$, and ranged from 0 (Canada Lake) to $74 \%$ (Squaw Lake). THg and $\mathrm{MeHg}$ concentrations in zooplankton were positively correlated $\left(r^{2}=0.32, p=0.0002\right)$. There were no significant differences in the mean whole body $\mathrm{THg}$ concentrations (mean: $0.05 \mu \mathrm{g} \mathrm{g}^{-1}$, range: $0.01-0.14 \mu \mathrm{g} \mathrm{g}^{-1}, p=0.44$ ) for the four crayfish species (Orconectes limosus, $O$. robustus, Procambarus acutus and $O$. propinquus), nor for whole body $\mathrm{THg}$ (mean: $0.05 \mu \mathrm{g} \mathrm{g}^{-1}$ ) and tail $\mathrm{THg}$ concentrations (mean: $0.06 \mu \mathrm{g} \mathrm{g}^{-1}$ ). Crayfish whole body THg concentrations were significantly correlated $\left(r^{2}=\right.$ 0.94, $p<0.0001, n=39$ ) with tail THg concentrations. Prey fish $\mathrm{Hg}$ concentrations (mean, range) were: banded killifish $\left(0.07,0.04-0.11 \mu \mathrm{g} \mathrm{g}^{-1}\right)$, golden shiner $(0.10$, $\left.0.07-0.14 \mu \mathrm{g} \mathrm{g}^{-1}\right)$, and creek chub $(0.11,0.05$ $0.15 \mu \mathrm{g} \mathrm{g}^{-1}$ ).

\section{Upper food web}

Fish total $\mathrm{Hg}$ concentrations (mean, range) were: pumpkinseed sunfish $\left(0.10,0.03-0.19 \mu \mathrm{g} \mathrm{g}^{-1}\right)$, brown bullhead $\left(0.10,0.07-0.14 \mu \mathrm{g} \mathrm{g}^{-1}\right)$, smallmouth bass $(0.11$, $\left.0.04-0.33 \mu \mathrm{g} \mathrm{g}^{-1}\right)$, largemouth bass $(0.12,0.04-0.23 \mu \mathrm{g}$ $\left.\mathrm{g}^{-1}\right)$, and yellow perch $\left(0.16,0.04-0.46 \mu \mathrm{g} \mathrm{g}{ }^{-1}\right.$, Fig. 2). $\mathrm{Hg}$ concentrations in $7 \%$ of all fish and $12 \%$ of yellow perch equivalent samples exceeded the EPA tissue criterion for $\mathrm{MeHg}$ in fish $\left(0.3 \mu \mathrm{g} \mathrm{g}^{-1}\right)$. Ten of the 44 lakes (23\%) had at least one fish sample with $\mathrm{Hg}$ concentration above $0.3 \mu \mathrm{g} \mathrm{g}^{-1}$ (Fig. 3), and 5 of those 10 lakes were not currently listed on the New York State fish consumption advisory. Note that $28(64 \%), 21(48 \%)$ and $4(9 \%)$ of the 44 lakes had at least one fish (YPE) in excess of the $0.16 \mu \mathrm{g} \mathrm{g}^{-1}, 0.21 \mu \mathrm{g} \mathrm{g}^{-1}$, and $0.42 \mu \mathrm{g} \mathrm{g}^{-1} \mathrm{Hg}$ threshold values, respectively, for adverse effects on common loon health (Fig. 3). There was a high density of lakes with elevated $\mathrm{Hg}$ concentrations in zooplankton and fish (YPE) in the southwestern part of our study area (Fig. 4). The study conducted by Driscoll et al. (1991) showed a large number of lakes acidified by acidic deposition in the southwestern Adirondacks (Fig. 4).

Total Hg concentrations in common loon blood (FLU) had a mean of $1.34 \mu \mathrm{g} \mathrm{g}^{-1}$, and ranged from 0.36 (Clear Pond) to $5.87 \mu \mathrm{g} \mathrm{g}^{-1}$ (Ferris Lake). Hg concentrations in $9 \%$ of all the loon blood samples (FLU) were greater than $3.0 \mu \mathrm{g} \mathrm{g}^{-1}$, while 13 of the study lakes (30\%) had at least one loon blood sample with a $\mathrm{Hg}$ concentration greater than $3.0 \mu \mathrm{g} \mathrm{g}^{-1}$. Like zooplankton and fish, the spatial distribution patterns for FLU $\mathrm{Hg}$ concentrations in the common loon population showed an abundance of lakes with elevated concentrations in the southwestern Adirondacks (Fig. 4). Overall, $\mathrm{Hg}$ concentrations increased across the aquatic food web in the order of crayfish, zooplankton, prey fish, fish and common loon (Fig. 2).

Factors affecting $\mathrm{Hg}$ bioaccumulation

\section{Lake chemistry effects}

Hg concentrations in aquatic biota were strongly influenced by lake water chemistry. Since collinearity was detected for the lake water chemistry variables in the cluster 
Fig. 2 Mercury concentrations (mean \pm standard deviation) in biota, whole body, except for zooplankton (dry weight) all samples were based on wet weight

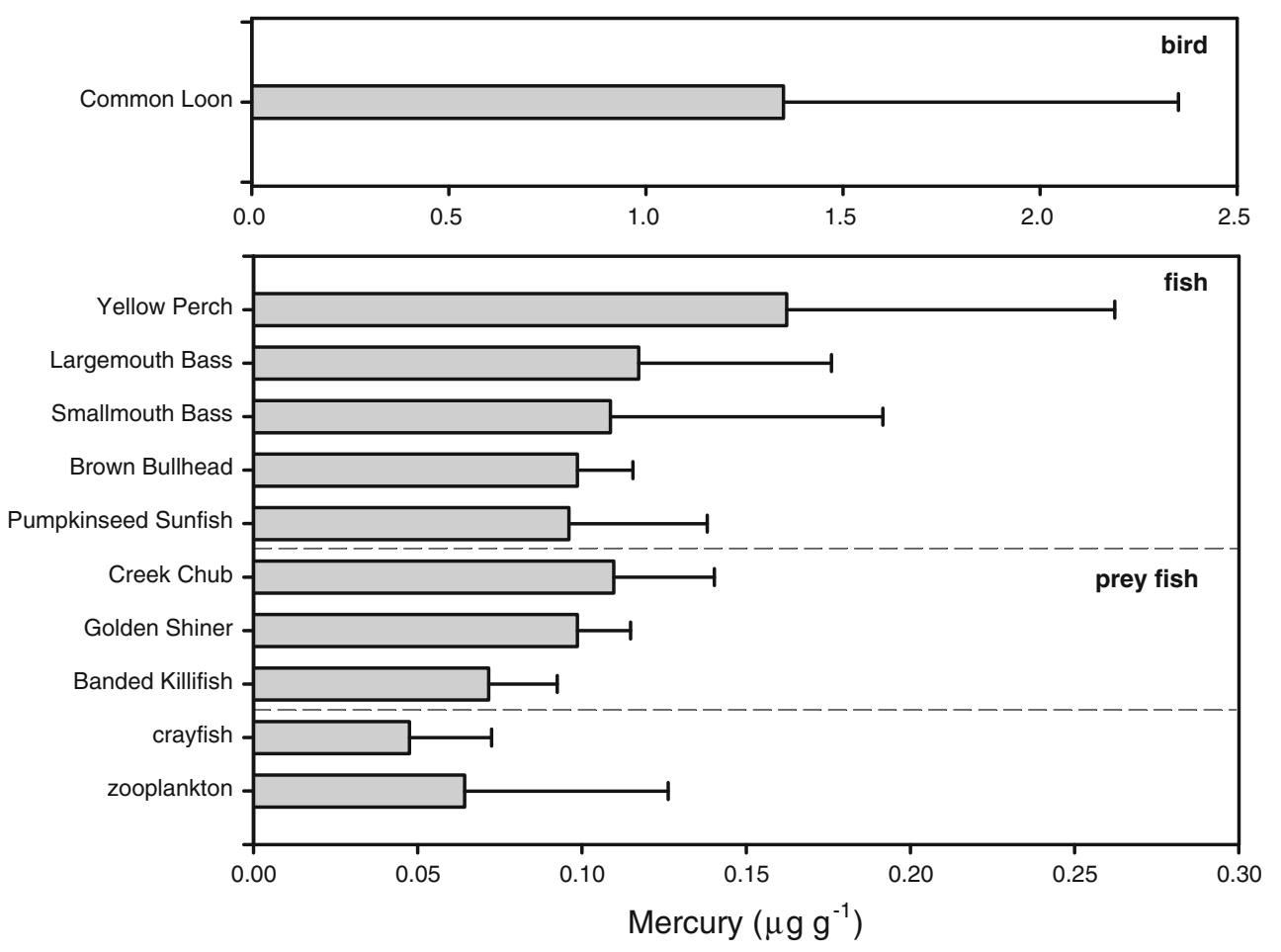

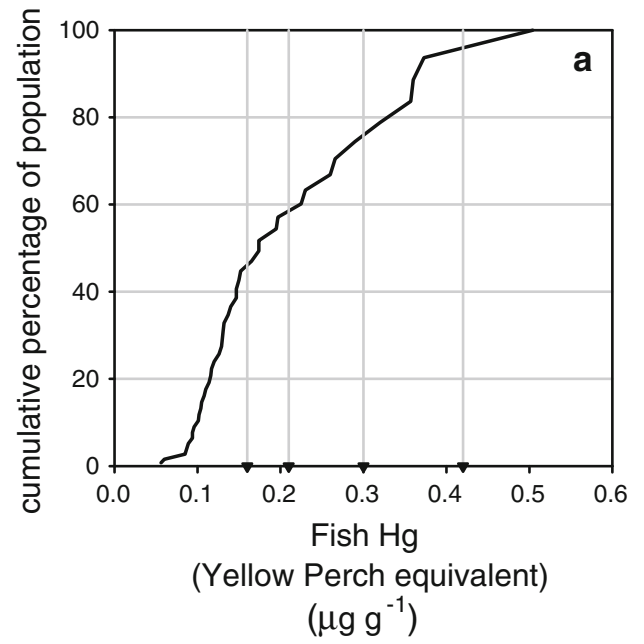

Fig. 3 Mean $\mathrm{Hg}$ concentrations in fish (whole body, yellow perch equivalent values, $\mu \mathrm{g} \mathrm{g}^{-1}$, ww; $\mathbf{a}$ and common loons (blood, female loon unit values, $\mu \mathrm{g} \mathrm{g}^{-1}$; $\mathbf{b}$ for the cumulative distribution of lakes sampled. The gray vertical lines in the fish population plot a represent the threshold values of $0.16,0.21$ and $0.42 \mu \mathrm{g} \mathrm{g}^{-1}$ for adverse effects

analysis, linear multiple regressions were used to predict biotic $\mathrm{Hg}$ concentrations from lake water chemistry variables. For zooplankton, the models obtained were: $\mathrm{MeHg}_{\text {zooplankton }}=0.2933-0.04068 \mathrm{pH}+0.05084 \mathrm{Al}_{\mathrm{o}}$ ( $p$ values for each of the estimated parameters were: 0.02 , 0.02 , and 0.04 , respectively; $r^{2}=0.51, n=33$ ), and $\mathrm{THg}_{\text {zooplankton }}=-0.55601+0.32578 \quad \mathrm{Al}_{\mathrm{o}}+0.00114$ elevation ( $p$ values: $0.03,<0.0001$, and 0.01 , respectively; $r^{2}=0.47, n=38$ ). For fish, the model obtained was:

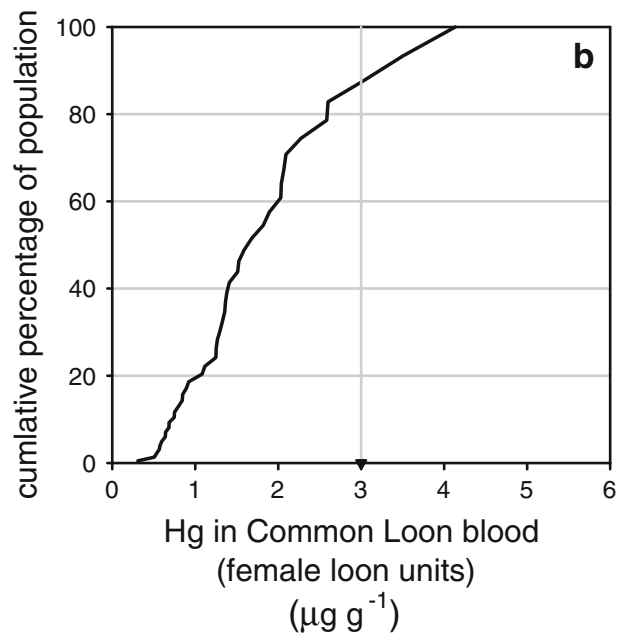

on common loon and $0.30 \mu \mathrm{g} \mathrm{g}^{-1}$ for the USEPA fish consumption advisory criterion. The gray vertical line in the loon population plot b represents the threshold concentration of $3.0 \mu \mathrm{g} \mathrm{g}^{-1}$ for the health concern criterion for the common loon

$\mathrm{Hg}_{\mathrm{YPE}}=0.28-0.019 \quad \mathrm{DOC}-0.00056 \quad \mathrm{ANC}+0.066$ $\mathrm{Al}_{\mathrm{m}}-0.28 \mathrm{MeHg} / \mathrm{THg}(p$ values: $0.0045,<0.0001$, $<0.0001$ and 0.0008 , respectively; $r^{2}=0.41, n=112$ ). While the regression models did not work well in predicting crayfish and loon blood $\mathrm{Hg}$, we did find a slight correlation between loon blood $\mathrm{Hg}$ concentrations with lake water $\mathrm{pH}\left(r^{2}=0.17, p=0.0004, n=241\right)$. We found no significant relationships between $\mathrm{Hg}$ concentrations in crayfish and $\mathrm{Hg}$ concentrations in littoral 
Fig. 4 Spatial distributions of $\mathrm{pH}$ in lake surface water and $\mathrm{Hg}$ concentrations in biota in the 44 Adirondack lakes, $\mu \mathrm{g} \mathrm{g}^{-1}$, i.e. zooplankton (MeHg), crayfish (THg), fish (yellow perch equivalent, YPE), and common loon (blood, female loon unit, FLU)

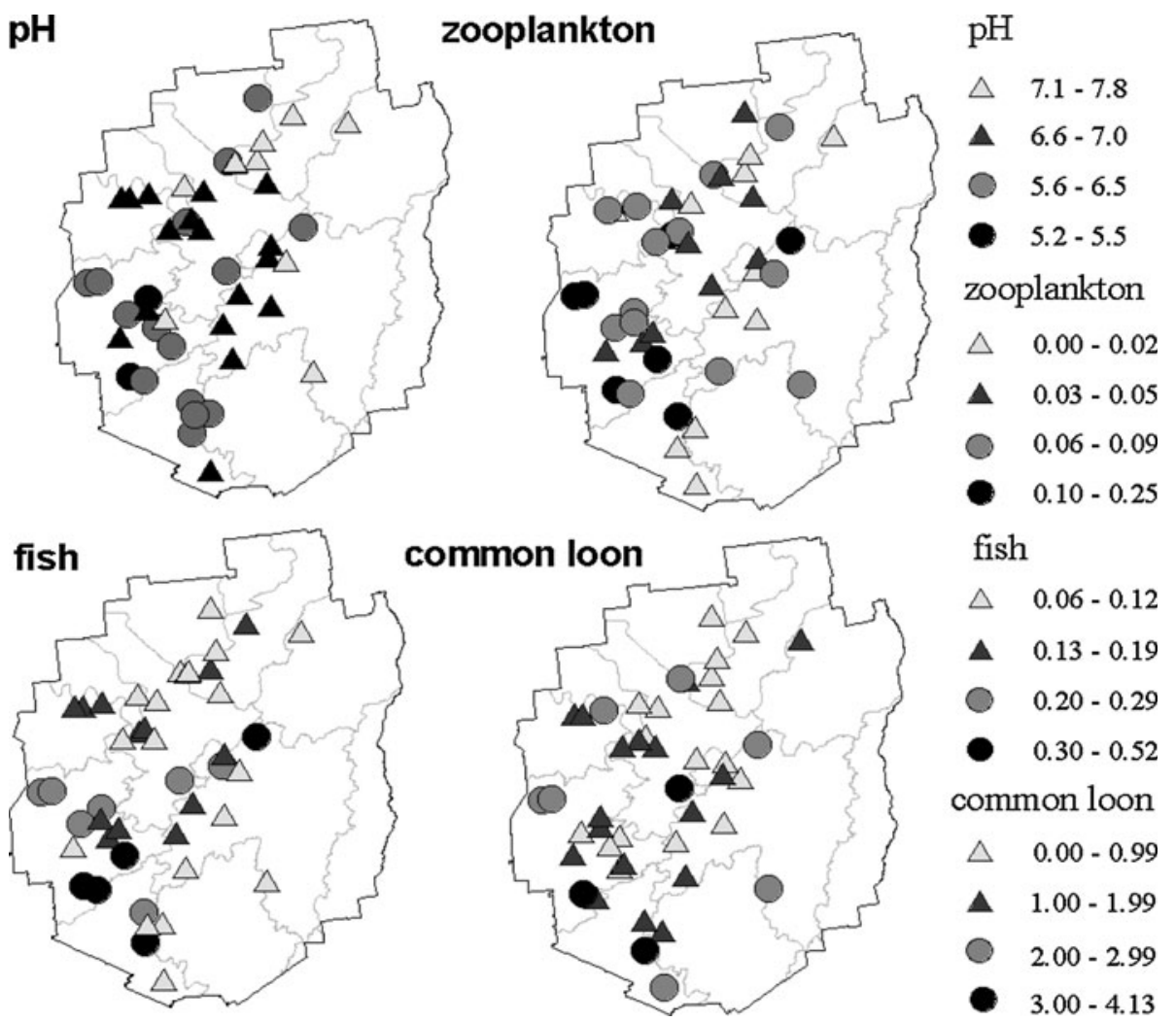

sediments. Our analysis suggests that the acid-base status of lake water ( $\mathrm{pH}, \mathrm{ANC}$ and $\mathrm{Al})$ is particularly related to $\mathrm{MeHg}$ accumulation in aquatic biota.

Although many studies have reported the important influence of the acid-base status on $\mathrm{Hg}$ in aquatic biota, the mechanism contributing to this pattern remains poorly defined. As our and other observations (e.g., Driscoll et al. 1994; Dittman and Driscoll 2009) show, surface water concentrations of $\mathrm{THg}$ and $\mathrm{MeHg}$ do not vary systematically with $\mathrm{pH}$. Thus, the correlation between lake $\mathrm{pH}$ and $\mathrm{Hg}$ concentrations in biota may be due to the influence of acidity on the assimilation of $\mathrm{MeHg}$ at the bottom of the food web and/or trophic transfer up the food web (Wyn et al. 2009).

The patterns of $\mathrm{Hg}$ in biota with ANC may be particularly relevant to air and water quality managers. Although there is variability in our observations, zooplankton, fish and loons all showed exponential increases in $\mathrm{Hg}$ concentrations with decreases in ANC (Fig. 5). The highest $\mathrm{Hg}$ concentrations in biota occurred in low ANC lakes that are likely to be severely impacted by acidic deposition (Driscoll et al. 2007c) and the biotic $\mathrm{Hg}$ concentrations decreased markedly with slight increases in ANC from these low values. This spatial pattern suggests potential interactions of acidic deposition and $\mathrm{Hg}$ contamination. Modest increases in ANC, which have been observed in low ANC lakes following atmospheric emission controls of sulfur dioxide and nitrogen oxides (Driscoll et al. 2007b) will likely have the co-benefit of decreasing $\mathrm{Hg}$ concentrations in biota.

The strong linkage of $\mathrm{Hg}$ with $\mathrm{Al}$ is also interesting and has been previously reported (Driscoll et al. 1994), although the operating mechanism is also not clear. Elevated concentrations of $\mathrm{Al}$ are generally coincident with low pH values. Driscoll et al. (1994) speculated that Al competed with $\mathrm{Hg}$ in binding to the functional sites of DOC, and elevated concentrations of $\mathrm{Al}$ would, therefore, increase the bioavailability of $\mathrm{Hg}$. Adams et al. (2009) suggested that elevated Al contributed to nutrient limitations of aquatic productivity of Adirondack lakes and as a result enhanced the bioconcentration of $\mathrm{Hg}$ at the base of the food web.

\section{Biologic effects}

Generally, MeHg BAFs increased in the order of crayfish (5.7), zooplankton (5.9), prey fish (6.2), fish (6.3) and common loons (7.2). The values of MeHg BAFs found for this study were consistent with those reported in the literature (crayfish, Alpers et al. 2008; zooplankton, Back and Watras 1995; Pickhardt et al. 2005; fish, Driscoll et al. 1994; loons, Evers et al. 2004). Zooplanktons are near the bottom of the aquatic food chain, but their $\mathrm{MeHg} \mathrm{BAF}$ 


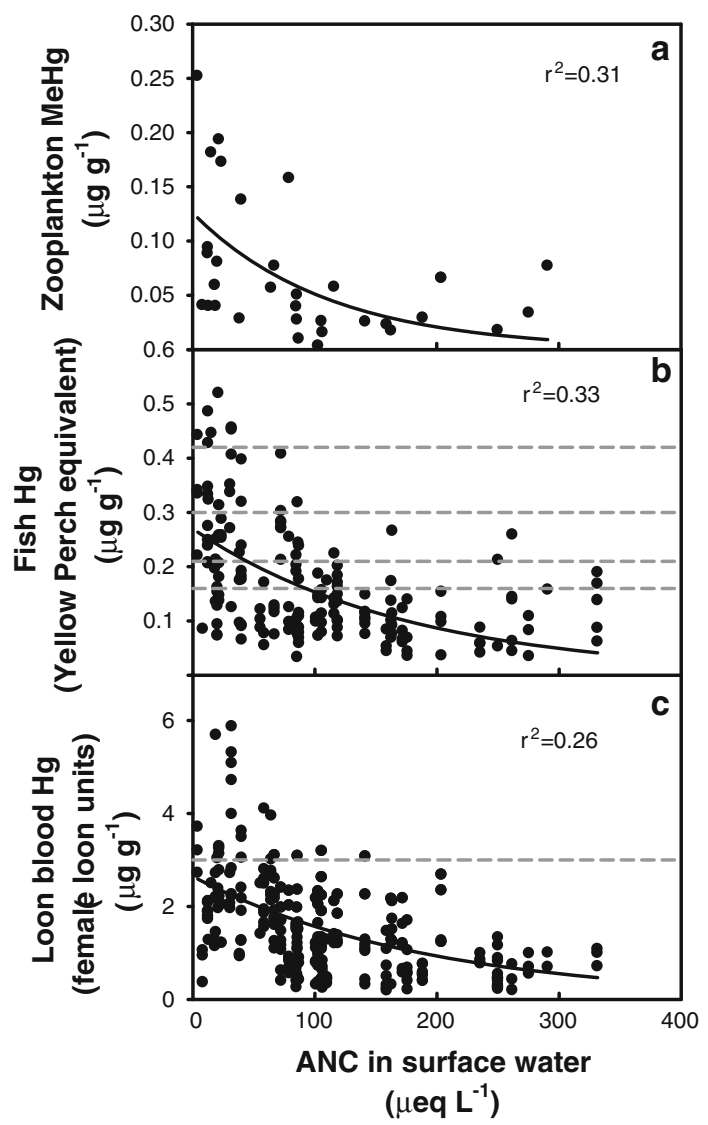

Fig. 5 Relationships between acid neutralizing capacity (ANC) and $\mathrm{Hg}$ concentrations in zooplankton (a), fish (b), and common loons (c). The exponential decay models fitted were: $y=0.126 \mathrm{e}^{-0.009 \mathrm{x}}(\mathbf{a})$, $y=0.2698 \mathrm{e}^{-0.0057 \mathrm{x}}(\mathbf{b})$, and $y=2.644 \mathrm{e}^{-0.0052 \mathrm{x}}(\mathbf{c})$, respectively. The $p$ values for the three models are $0.002,<0.0001$ and $<0.0001$, respectively. The dashed lines of $0.16,0.21,0.3$, and $0.42 \mu \mathrm{g} \mathrm{g}^{-1}$ in plot $\mathbf{b}$, and $3 \mu \mathrm{g} \mathrm{g}^{-1}$ in plot $\mathbf{c}$ represent the same criteria values as in Fig. 3

values are relatively high in view of low trophic position (Driscoll et al. 2007c). These relatively large MeHg BAF values demonstrate generally the importance of the lower food web in setting the magnitude of $\mathrm{Hg}$ concentration for higher trophic levels and ultimately controlling exposure to wildlife and human (Driscoll et al. 1994; Kamman et al. 2005). Lake chemistry parameters were more strongly related to $\mathrm{Hg}$ concentrations in zooplankton than $\mathrm{Hg}$ concentrations in any other biota. Crayfish, one of the largest benthic invertebrates, are an important food source for other organisms, such as predatory fish (yellow perch) and fish-eating birds (common loon) (Pennuto et al. 2005).

The values of fish $\mathrm{Hg}$ concentrations were within ranges found in other studies for Adirondack lakes (0.09-1.11 $\mu \mathrm{g} \mathrm{g}^{-1}$, Dittman and Driscoll 2009; 0.001-3.24 $\mu \mathrm{g} \mathrm{g}^{-1}$, Simonin et al. 2008) and water bodies of the northeastern U.S. (Kamman et al. 2005). As observed in many previous studies, fish $\mathrm{Hg}$ concentrations increased with fish length.
Simonin et al. (2008) found the relationships between $\mathrm{Hg}$ concentrations and fish length were more significant ( $r^{2}$ ranged from 0.76 to 0.87 , varied with fish species) for individual lakes than for groups of lakes.

Although we did not find statistically significant differences in blood $\mathrm{Hg}$ concentrations in female (mean: $1.48 \mu \mathrm{g} \mathrm{g}^{-1}$, range: $0.43-5.87 \mu \mathrm{g} \mathrm{g}^{-1}$ ) and male loons $\left(1.95,0.62-3.85 \mu \mathrm{g} \mathrm{g}^{-1}\right)$, male body burdens exceeded females, and blood $\mathrm{Hg}$ concentrations in adult loons (1.71, $0.43-5.87 \mu \mathrm{g} \mathrm{g}^{-1}$ ) were significantly higher than chicks $\left(0.26,0.06-0.82 \mu \mathrm{g} \mathrm{g}^{-1}\right)$. These patterns follow other studies (Evers et al. 1998; Meyer et al. 1998; Scheuhammer et al. 1998; Rimmer et al. 2010). Hg concentrations in crayfish were positively correlated with $\mathrm{Hg}$ concentrations in zooplankton (THg, $r^{2}=0.44, p=0.004, n=40$ ), fish (YPE, $r^{2}=0.14, p<0.0001, n=101$ ) and loons (FLU, $\left.r^{2}=0.41, p<0.0001, n=132\right)$. Using linear multiple regression, the equation obtained to predict $\mathrm{Hg}$ in loon blood from $\mathrm{Hg}$ in yellow perch and zooplankton was: $\mathrm{Hg}_{\mathrm{FLU}}=0.69565+3.407 \mathrm{Hg}_{\text {yellow perch }}+4.38355$ $\mathrm{Hg}_{\text {zooplankton }}(p$ values: $0.0004,0.01$ and 0.03 , respectively; $\left.r^{2}=0.19, n=105\right)$. The relationships among $\mathrm{Hg}$ concentrations in various taxa of biota reflect the common $\mathrm{Hg}$ transfer mechanism(s) along the aquatic food chain and to larger piscivorous animals. Variations of $\mathrm{Hg}$ concentrations for similar species (zooplankton, crayfish, fish, and loons) in similar habitats and areas are likely due to food web complexity and dietary patterns.

\section{Spatial landscape effects}

The variability of $\mathrm{Hg}$ concentrations in biota for nearby lakes indicated that landscape factors affect $\mathrm{Hg}$ bioaccumulation in addition to lake chemistry and biology. We hypothesized that landscape characteristics would influence lake physicochemical properties, $\mathrm{Hg}$ inputs to lakes and the feeding habitat of biota, and therefore, affect the magnitude of $\mathrm{Hg}$ contamination. Most of the land cover area for the watersheds of the study lakes is deciduous forest, as deciduous forest occupies 54\%, coniferous forest $14 \%$, mixed forest $6 \%$, woody wetlands $11 \%$, and open water $12 \%$, respectively, of the total area of the watersheds to the study lakes. No significant relationships were found between the percentages of land cover class and lake water chemistry parameters, or $\mathrm{Hg}$ concentrations in lake water or aquatic biota. We only found a slight correlation between the percentages of watershed area as mixed forest and $\mathrm{Hg}$ concentrations in common loons (FLU, $r^{2}=0.10$, $p<0.0001$ ). Note the land cover classes of the study lakes did not vary substantially as the dominant land cover is forest. Relationships may have been evident if there was more variation in watershed land cover classes. For example, Kramar et al. (2005) reported a stronger 
relationship $\left(r^{2}=0.55, p<0.0001\right)$ between $\mathrm{Hg}$ concentrations in common loon and land cover classes, (i.e., crop land, shrub land, wetlands) for the major lakes and eleven smaller ponds in northwest Maine.

The elevation in Adirondack Park is generally high along a southwest-northwest transect. The elevation range for the Park is $23-1625 \mathrm{~m}$, while the study lakes range from 429 to $623 \mathrm{~m}$. Both $\mathrm{pH}\left(r^{2}=0.11, p=0.03\right)$ and ANC $\left(r^{2}=0.09, p=0.05\right)$ were weakly negatively related with lake elevation. Although we did not find relationships between elevation and $\mathrm{Hg}$ concentrations in zooplankton, crayfish, fish and loons, we did find slight positive correlations between elevation and $\mathrm{MeHg} \mathrm{BAF}$ in zooplankton $\left(r^{2}=0.15, p=0.01, n=28\right)$, crayfish $\left(r^{2}=0.21\right.$, $p<0.0001, n=24)$ and fish $\left(r^{2}=0.14, p<0.0001\right.$, $n=62$ ). The mechanism for the elevation effect on $\mathrm{Hg}$ bioaccumulation in aquatic ecosystems is not clear. High elevation lakes are likely to receive greater atmospheric $\mathrm{Hg}$ deposition (Miller et al. 2005) resulting in newly deposited $\mathrm{Hg}$ that is likely more available to biota. Furthermore, high elevation lakes receive greater inputs of acidic deposition and have shallow soils and surficial deposits which make them more sensitive to surface water acidification (Driscoll et al. 1991; Ito et al. 2002). We did not note a relationship between $\mathrm{THg}$ or MeHg in lake water and elevation. This lack of association suggests that the spatial patterns of $\mathrm{Hg}$ in biota with elevation may be driven more by the influence of lake $\mathrm{pH}$ on $\mathrm{MeHg}$ bioavailability and/or trophic transfer.

\section{Summary}

The spatial distribution patterns of $\mathrm{Hg}$ concentrations in lake water, littoral sediments, zooplankton, crayfish, fish and common loon showed considerable variation across the 44 Adirondack lakes. Consistent with previous studies, $\mathrm{Hg}$ strongly bioaccumulated in zooplankton, fish and common loon blood. Our spatial analysis indicates that lakes with the highest concentrations of $\mathrm{Hg}$ in aquatic biota are generally located in the southwestern portion of the Adirondack Park, where there is a high density of lakes that have been acidified by acidic deposition (Fig. 4; Driscoll et al. 1991). Many of the lakes studied have $\mathrm{Hg}$ concentrations in fish and common loon blood which exceed criteria established for the protection of human and wildlife health. We observed a marked increase in the $\mathrm{Hg}$ concentration in biota with decreases in lake $\mathrm{pH}$ and ANC. Modest increases in ANC in low ANC lakes (associated with atmospheric emission controls and decreased in acidic deposition) would likely have the co-benefit of decreasing Hg contaminations in biota.

The Adirondacks is a region characterized by relatively high concentrations of $\mathrm{Hg}$ in aquatic biota (Driscoll et al.
1994; Evers et al. 2007). Several factors undoubtedly contribute to this pattern. Watersheds of the Adirondacks are largely forested. Forests greatly enhance atmospheric deposition of $\mathrm{Hg}$ due to the scavenging of gaseous and particulate $\mathrm{Hg}$ by the forest canopy. There are an abundance of wetlands in Adirondack watersheds which are important in the transport of $\mathrm{Hg}$ to downstream lakes and the production of $\mathrm{MeHg}$ (Selvendiran et al. 2008). Adirondack lakes are relatively unproductive, a condition which enhances bioconcentration of $\mathrm{Hg}$ (Chen and Folt 2005). Our analyses show that $\mathrm{Hg}$ concentrations in fish and common loon are directly related to $\mathrm{MeHg}$ concentrations in the lower food web. The most distinct factors influencing biotic $\mathrm{Hg}$ concentrations in this study were lake $\mathrm{pH}$ and ANC. Many Adirondack lakes are naturally acidic, but have also been acidified by elevated inputs of acidic deposition. It would appear that the status of the Adirondacks as a biological $\mathrm{Hg}$ hotspot is due to its landscape characteristics which make the region sensitive to moderate inputs of $\mathrm{Hg}$ but also ongoing effects of acidic deposition.

Acknowledgments The New York State Energy Research and Development Authority, Wildlife Conservation Society, Natural History Museum of the Adirondacks, New York State Department of Environmental Conservation, and the Audubon Society of New York provided support and in-kind assistance for this project. We thank M. Watson and G. Lampman of the New York State Energy Research and Development Authority; K. Roy and S. Capone of the Adirondack Lakes Survey Corporation; E. Osmancevic of the Center for Environmental Systems Engineering Laboratory at Syracuse University; J. Ozard, J. Loukmas, J. Sutherland, D. Adams, B. Bauer, D. Bloomquist, and T. Gudlewski of New York State Department of Environmental Conservation; A. Sauer, G. Lee and the loon monitoring and banding field staff of the former Adirondack Cooperative Loon Program; and D. Pepin formerly of BioDiversity Research Institute.

Open Access This article is distributed under the terms of the Creative Commons Attribution Noncommercial License which permits any noncommercial use, distribution, and reproduction in any medium, provided the original author(s) and source are credited.

\section{References}

Adams RM, Twiss MR, Driscoll CT (2009) Patterns of mercury accumulation among seston in lakes of the Adirondack Mountains, New York. Environ Sci Technol 43:4836-4842

Alpers CN, Stewart AR, Saiki MK, Marvin-DiPasquale MC, Topping BR, Rider KM, Gallanthine SK, Kester CA, Rye RO, Antweiler RC, De Wild JF (2008) Environmental factors affecting mercury in Camp Far West Reservoir, California, 2001-03. U.S. Geological Survey Scientific Investigations Report 2006-5008

APHA/AWWA/WEF (1998) Standard methods for the examination of water and wastewater, 20th edn. American Public Health Association, American Water Works Association, and Water Environment Federation, Washington, DC

Back RC, Watras CJ (1995) Mercury in zooplankton of Northern Wisconsin Lakes: taxonomic and site-specific trends. Water Air Soil Pollut 80:931-938 
Bookman R, Driscoll CT, Engstrom DR, Effler SW (2008) Local to regional emission sources affecting mercury fluxes to New York lakes. Atmos Environ 42:6088-6097

Burgess NM, Meyer MW (2008) Methylmercury exposure associated with reduced productivity in common loons. Ecotoxicology 17:83-91. doi:10.1007/s10646-007-0167-8

Bushey JT, Driscoll CT, Mitchell MJ, Selvendiran P, Montesdeoca MR (2008) Mercury transport in response to storm events from a northern forest landscape. Hydrol Process 22:4813-4826

Chen CY, Folt CL (2005) High plankton densities reduce mercury biomagnification. Environ Sci Technol 39:115-121

Chen CY, Stemberger RS, Kamman NC, Mayes BM, Folt CL (2005) Patterns of $\mathrm{Hg}$ bioaccumulation and transfer in aquatic food webs across multi-lake studies in the northeast US. Ecotoxicology 14:135-147

Dennis IF, Clair TA, Driscoll CT, Kamman N, Chalmers A, Shanley J, Norton SA, Kahl S (2005) Distribution patterns of mercury in lakes and rivers of Northeastern North America. Ecotoxicology 14:113-123

Dittman JA, Driscoll CT (2009) Factors influencing changes in mercury concentrations in lake water and yellow perch (Perca flavescens) in Adirondack lakes. Biogeochemistry 93:179-196

Dittman JA, Shanley JB, Driscoll CT, Aiken GR, Chalmers AT, Towse JE (2009) Ultraviolet absorbance as a proxy for total dissolved mercury in streams. Environ Pollut 157:1953-1956

Driscoll CT, Newton RM, Gubala CE, Baker JP, Christensen S (1991) Adirondack mountains. In: Charles DE (ed) Acidic deposition and aquatic ecosystems: regional case studies. Springer, New York, p 133

Driscoll CT, Yan C, Schofield CL, Munson R, Holsapple J (1994) The mercury cycle and fish in the Adirondack lakes. Environ Sci Technol 28(3):136A-143A

Driscoll CT, Holsapple J, Schofield CL, Munson R (1998) The chemistry and transport of mercury in a small wetland in the Adirondack region of New York, USA. Biogeochemistry 40: 137-146

Driscoll CT, Abbott ML, Bullock R, Jansen J, Leonard D, Lindberg SE, Munthe J, Pirrone N, Nilles M (2007a) Airsheds and watersheds. In: Harris R, Krabbenhoft DP, Mason R, Murray MW, Reash R, Saltman T (eds) Ecosystem responses to mercury contamination: indicators of change. SETAC, CRC Press, Boca Raton, FL

Driscoll CT, Driscoll KM, Roy KM, Dukett J (2007b) Changes in the chemistry of lakes in the Adirondack region of New York following declines in acidic deposition. Appl Geochem 22:11811188

Driscoll CT, Han YJ, Chen CY, Evers DC, Lambert KF, Holsen TM, Kamman NC, Munson RK (2007c) Mercury contamination in forest and freshwater ecosystems in the Northeastern United States. Bioscience 57:17-28

EPA (2001) Method 1630: methyl mercury in water by distillation, aqueous ethylation, purge and trap, and CVAFS (EPA-821-R01-020, January 2001). Office of water, office of science and technology, engineering and analysis division 4303. US Environmental Protection Agency, Washington, DC

EPA (2002) Method 1631, revision E: mercury in water by oxidation, purge and trap, and cold vapor atomic fluorescence spectrometry (EPA-821-R-01-019, August 2002). Office of water, office of science and technology, engineering and analysis division 4303. US Environmental Protection Agency, Washington, DC

Evers DC, Kaplan JD, Meyer MW, Reaman PS, Major A, Burgess N, Braselton WE (1998) Bioavailability of environmental mercury measured in Common Loon feathers and blood across North American. Environ Tox Chem 17:173-183
Evers DC, Taylor KM, Major A, Taylor RJ, Poppenga RH, Scheuhammer AM (2003) Common loon eggs as indicators of methylmercury availability in North America. Ecotoxicology 12:69-81

Evers DC, Lane OP, Savoy L, Goodale W (2004) Assessing the impacts of methylmercury on piscivorous wildlife using a wildlife criterion value based on the Common Loon, 1998-2003. Report BRI 2004-05 submitted to the Maine Department of Environmental Protection. BioDiversity Research Institute, Gorham, Maine

Evers DC, Han YJ, Driscoll CT, Kamman NC, Gooodale MW, Lambert KF, Holsen TM, Chen CY, Clair TA, Butler T (2007) Biological mercury hotspots in the Northeastern United States and Southeastern Canada. Bioscience 57:29-43

Evers DC, Savoy LJ, DeSorbo CR, Yates DE, Hanson W, Taylor KM, Siegel LS, Cooley JH Jr, Bank MS, Major A, Munney K, Mower BF, Vogel HS, Schoch N, Pokras M, Goodale JF (2008) Adverse effects from environmental mercury loads on breeding common loons. Ecotoxicology 17:69-81

Fry JA, Coan MJ, Homer CG, Meyer DK, Wickham JD (2009) Completion of the National Land Cover Database (NLCD) 1992-2001 land cover change retrofit product. U.S. Geological Survey open-file report 2008-1379

George BM, Batzer D (2008) Spatial and temporal variations of mercury concentrations in Okefenokee invertebrates: Southeast Georgia. Environ Pollut 152:484-490

Hurley JP, Benoit JM, Babiarz CL, Shafer MM, Andren AW, Sullivan JR, Hammond R, Webb DA (1995) Influences of watershed characteristics on mercury concentrations in Wisconsin rivers. Environ Sci Technol 29:1867-1875

Ito M, Mitchell MJ, Driscoll CT (2002) Spatial patterns of precipitation quantity and chemistry and air temperature in the Adirondack region of New York. Atmos Environ 36:1051-1062

Kamman NC, Lorey PM, Driscoll CT, Estabrook R, Major A, Pientka B (2003) Assessment of mercury in waters, sediments, and biota of VT and NH lakes using a geographically randomized design. Environ Tox Chem 23:5

Kamman NC, Burgess NM, Driscoll CT, Simonin HA, Goodale W, Linehan J, Estabrook R, Hutcheson M, Major A, Scheuhammer AM, Scruton DA (2005) Mercury in freshwater fish of Northeast North America-a geographic perspective based on fish tissue monitoring databases. Ecotoxicology 14:163-180

Kramar D, Goodale WM, Kennedy LM, Carstensen LW, Kaur T (2005) Relating land cover characteristics and common loon mercury levels using geographic information systems. Ecotoxicology 14:253-262

Lasorsa B, Allen-Gil S (1995) The methylmercury to total mercury ratio in selected marine, freshwater, and terrestrial organisms. Water Air Soil Pollut 80:905-913

Mason RP, Reinfelder JR, Morel FMM (1996) Uptake, toxicity, and trophic transfer of mercury in a coastal diatom. Environ Sci Technol 30:1835-1845

Meyer MW, Evers DC, Hartigan J (1998) Patterns of Common Loon (Gavia immer) mercury exposure, reproduction, and survival in Wisconsin, USA. Environ Tox Chem 17:184-190

Miller EK, Vanarsdale A, Keeler GJ, Chalmers A, Poissant L, Kamman NC, Brulotte R (2005) Estimation and mapping of wet and dry mercury deposition across Northeastern North America. Ecotoxicology 14:53-70

Pennuto CM, Lane OP, Evers DC, Taylor RJ, Loukmas J (2005) Mercury in the Northern Crayfish, Orconectes virilis (Hagen), in New England, USA. Ecotoxicology 14:149-162

Pickhardt PC, Folt CL, Chen CY, Klaue B, Blum JD (2005) Impacts of zooplankton composition and algal enrichment on the 
accumulation of mercury in an experimental freshwater food web. Sci Total Environ 339:89-101

Rimmer CC, Miller EK, McFarland KP, Taylor RJ, Faccio SD (2010) Mercury bioaccumulation and trophic transfer in the terrestrial food web of a montane forest. Ecotoxicology 19:697-709

Scheuhammer AM, Atchison CM, Wong AHK, Evers DC (1998) Mercury exposure in breeding common loons (Gavia immer) in central Ontario, Canada. Environ Tox Chem 17(2):191-196

Selvendiran P, Driscoll CT, Bushey JT, Montesdeoca MR (2008) Wetland influence on mercury fate and transport in a temperate forested watershed. Environ Pollut 154:46-55

Selvendiran P, Driscoll CT, Montesdeoca MR (2009) Mercury dynamics and transport in two Adirondack lakes. Limnol Oceanogr 54(2):413-427
Simonin HA, Jefferey JL, Skinner LC, Roy KM (2008) Lake variability: key factors controlling mercury concentrations in New York State fish. Environ Pollut 154:107-115

Slotton DG, Reuter J, Goldman CR (1995) Mercury uptake patterns of biota in a seasonally anoxic northern California Reservoir. Water Air Soil Pollut 80:841-850

Watras CJ, Bloom NS (1992) Mercury and methylmercury in individual zooplankton: implication for bioaccumulation. Limnol Oceanogr 37:1313-1318

Wyn B, Kidd KA, Burgess NM, Curry RA (2009) Mercury biomagnification in the food webs of acidic lakes in Kejimkujik National Park and National Historic Site, Nova Scotia. Can J Fish Aquat Sci 66:1532-1545 